\title{
Study on Yangjiabu Village Woodblock Spring Festival Paintings-Culture Tourism Under Vision of Intangible Cultural Heritage
}

\author{
Lu Chunxiao \\ School of Historical Culture and Tourism \\ Weifang University \\ Weifang, China \\ Luchunxiao2206@126.com
}

\begin{abstract}
The aim of the study is to find out the Innovative modes and new ways of the integration of intangible cultural heritage and cultural tourism. We provide a case study and field investigation of the Yangjiabu village to achieve this purpose. As a folk manufacturing village in China, Yangjiabu village woodblock Spring festival paintings manufacture technique which not only has high historical value, but also provides high possibility of culture tourism is famous at home and abroad. Yangjiabu's woodblock Spring festival paintings manufacture technique as intangible cultural heritage is closely combined with culture tourism. The paper lays particular emphasis on the cultural tourism development of intangible cultural heritage in Yangjiabu village. This paper also explains the interactive relations between them and studies the harmonious development way of intangible cultural heritage and tourism culture. However, in the process of development of cultural tourism, many problems are also exposed. The results suggest that the relevant departments need to take measures such as festival tourism mode to solve these problems and improve its development.
\end{abstract}

Keywords-culture tourism; Yangjiabu village; woodblock Spring festival paintings culture; intangible cultural heritage

\section{INTRODUCTION}

Yangjiabu village is located in Weifang, ShanDong, northeast of the Hanting District, 15 kilometers away from the urban area. The village is famous for producing woodblock Spring festival paintings on a large scale at home and abroad. The production history of Yangjiabu's woodblock Spring festival paintings can be traced back to late Ming dynasty. All paintings were produced in the way of traditional manufacture technique in that time. In the Qing dynasty, it has reached its meridian and influenced the whole north China. Festival and auspicious are the eternal theme of the Yangjiabu's spring festival paintings. At the same time, the paintings will change a subject every year, if there are some new ideas, new things, these new ideas and new things can be immediately reflected in paintings. Therefore, the paintings become a folklore symbol of agricultural society in north of China. As Wu Bingan puts it, "many fabulous works of art and skills are often from the mysterious inheritance, which is the original basis of cultural diversity[1]. Yangjiabu's woodblock Spring festival paintings also indirectly record the Chinese local-style dwelling houses and civil society life; they are the collective memory of
Chinese folk culture. Today, the village which only has 1150 residents produces more than 20 million spring festival paintings every year. These paintings are exported to more than 100 countries and regions. Rich folk culture in Yangjiabu has attracted many tourists. This village becomes more and more important in Shandong folk tourism. In this village, people can enjoy the various kinds of Spring festival paintings production tools and original woodblock form the Ming dynasty. Curious tourists can watch the complete production process and experience the connotation of Chinese traditional culture. In 2002, the 76-year-old Yang Luoshu who is a representative of craftsmen is awarded "folk crafts master" honorary title by UNESCO in order to reward his great contribution. In 2006, Yangjiabu's woodblock Spring festival paintings manufacture technique was listed in the first national intangible cultural heritage directory with the approval of Central Government. However, there are many difficulties and problems in the development of Yangjiabu's woodblock Spring festival paintings.

First of all, modern machines production and marketoriented transformation form huge impact on traditional production techniques and quality. At present, Yangjiabu's craftsmen are mostly local people without systematic training. Due to restrictions of the education level and comprehensive qualities, they can't fully understands the woodblock Spring festival paintings' cultural value and spiritual connotation. Under the impact of the commercial tide, there has been a new phenomenon of opportunism and cost-saving, which has greatly reduced the quality of paintings. At the same time, in order to pursue the economic interests, there have been largescale machine paintings which are posed as hand-made Spring festival paintings. For example, the famous paintings craftsman Yang Luoshu's paintings have been repeatedly modelled by machine. These phenomena seriously affect the reputation of Yangjiabu village.

Secondly, the craftsmen are lack of enough successors. In the tide of market economy, the successors need to face the lower economic income and social status. If a successor wants to master complete technology process, they will spend a lot of time and energy. However, they will not get the corresponding income and return in a short time. Now, in addition to a few old craftsmen, almost no successor can comprehensively 
master the system of woodblock Spring festival paintings manufacture technique. This pessimistic situation will directly influence the development and inheritance of the woodblock Spring festival paintings culture.

Thirdly, the aesthetic view of paintings is far behind the times. With the progress of the times, the woodblock Spring festival paintings have become not essential whether in the countryside or in the city of China. The lack of innovation gives rise to the shrinking market and popular overlook. As the scholar $\mathrm{Fu}$ Zhuo and Fan Sha said, there has been even negative growth of its production[2]. In the face of modern society and market economy, the sales market of the paintings is shrinking and the paintings' cultural value is not fully taped.

\section{The NECESSITY OF COMBINING INTANGIBLE CUlturAL HeRitage With Cultural PRODUCT}

Unlike the tangible matter, the primary attribute of the intangible cultural heritage is nonphysical. This attribute of the intangible cultural heritage encounters many difficulties in the process of transmission and dissemination. Because it can't be directly perceived and saved as material products. The characteristics and effectiveness of the Intangible cultural heritage can be demonstrated and played only in the production of specific activities. Practice and display process are limited in the time, space and other aspects. Only the minorities have the opportunity to directly participate in or experience the process. For most people, intangible cultural heritage is mysterious and not easy to understand. Especially for the younger generation, intangible cultural heritage means outdated, old and traditional. with the development of modern society, the intangible cultural heritage has a great possibility of losing which is moving away from modern lifestyle. As a national collective memory and cultural genes, however, intangible cultural heritage is an important manifestation of cultural diversity. With the improvement of the degree of social civilization, the people have a more in-depth understanding of the intangible cultural heritage. We are aware that even in modern society; the intangible cultural heritage still plays an important role. The decline status quo of the intangible cultural heritage must be reversed. So that, expanding the scope of heritage and influence becomes the top priority of the development of intangible cultural heritage. Only when a growing number of people understand the intangible cultural heritage, its heritage and development will have a solid foundation.

Intangible cultural heritage and material cultural heritage have completely different attributes. However, it does not mean that the two are completely antagonistic. On the contrary, the spread of any intangible cultural heritage depends on material products. In order to be widely recognized and disseminated, the intangible cultural heritage must have a material carrier. That is to say, the intangible cultural heritage can have material shells and it can be cured into material products.

Material products can break through the restrictions of intangible cultural heritage. When the cultural product reaches the users and the consumers through the exchange of market, the cultural factors also will be disseminated to the audience, and then it will have a subtle influence on the audience. In the process of using the product, users and consumers can feel and understand not only the product itself but also the intangible cultural heritage. So that, the development of cultural products relying on intangible cultural heritage resources becomes necessary and reasonable. Among the many cultural products, cultural tourism routes are popular and effective. A good cultural tourism routes product can effectively convey the ancient traditional culture to the people of modern society. The intangible cultural heritage can be revitalized and energetic in this way. So, the combination of the two is a win-win situation.

\section{FolK TOURISM AND INTANGIBLE CUlturAl HERITAGE TOURISM}

With the development of cultural tourism, cultural factors are becoming more and more important in tourism. The intangible cultural heritage is a valuable asset of human civilization. Yangjiabu's woodblock Spring festival paintings Manufacture techniques and culture are an important statelevel intangible cultural heritage, and it embodies the traditional folk culture and customs in northern China. From the perspective of cultural tourism, Yangjiabu's woodblock Spring festival paintings manufacture techniques and culture have become an important tourist attraction. At the same time, the village has become an important folk tourist destination. This is an example of the combination of intangible cultural heritage and cultural tourism.

In a sense, this situation in Yangjiabu village reflects the new trend of tourism development. The combination of intangible cultural heritage and cultural tourism is imperative and promising. Reasonable development and utilization of intangible cultural heritage should be widespreadly concerned.

Yangjiabu is spatial distribution of intangible cultural heritage resources. During the development of cultural tourism, there are some dilemma and problems in the village. As a result, government departments and related enterprises should work hard together and take some effective measures to reverse this disadvantage situation. The folk cultural rescue measures should be started as soon as possible to attract the market attention and create favorable environment.

\section{A. Theme park construction}

The people who have a deep understanding of the paintings' culture are only two percent of the tourists[3]. According to the actual situation of Yangjiabu village tourism development, the government should plan and construct the key scenic combined with farm building. So that, tourists can participate in the process of practice and fully appreciate the esoteric meaning of traditional folk culture. In the display of intangible cultural heritage, the government departments and related enterprises should use modern high scientific and technological means to enrich the content of intangible cultural heritage. The relevant departments should construct Yangjiabu's woodblock Spring festival paintings theme view park for the interpretation of the folk culture and customs. At the same time, the content of the park should be rich and colorful. On-the-spot paintings, the farm experience for the carrier, strong flavor of rural amorous feelings should be fully displayed. If it can do this, it will let the visitors fully feel the charm of the Chinese traditional culture and the local customs. 
The unique interests and values is hidden behind in the brand[4]. In order to expand the influence, the relevant departments should speed up the cultivation of cultural brands. The only way to own a market is to have a famous brand[5]. Through brand effect, the theme park will enjoy considerable economic and social benefits. As a result, the development of tourism and traditional culture can be organically combined.

\section{B. The inheritance of folk culture}

Yangjiabu's woodblock Spring festival paintings manufacture technique is one of the national intangible cultural heritages. Handmade manufacture techniques must be kept. The traditional way of manufacture techniques can not only develop folk cultural tourism, but also cause the attention of the society. So that, we don't advocate using machine. The government should set up a special crafts school to realize the inheritance of Yangjiabu's spring festival paintings. Relying on cultural tourism platform, it can make the sets of product inheritance, sightseeing, tourism, entertainment festival consumption, video making for the integration of the cultural industry chain.

\section{The plan of further development}

On the basis of the traditional manufacture technique and rich cultural resources in the village, the local government should build a production platform and open workshops. The old craftsmen can show the sculpture printing, paintings template-making technology and folk performances in open workshops. Under the guidance of the craftsmen, tourists can participate in the working procedure. Through this way of deep experience, a number of tourists can fully appreciate manufacture techniques. So that, authentic local culture art and unique charm of the village will be widely broadcasted.

\section{Festivals mode}

Festivals mode often embodies the festive customs of a region and the unique folk culture. Tourists which participate in local festivals can not only experience and understand local folk culture, but also objectively broadcast local culture to the world. Thereby, festivals mode can attract more tourists to experience and appreciate the unique folk culture. A cultural form mainly rely on their own benefits to protect themselves to adapt to the changing times[6]. Obviously, the festive model is an effective way to earn economic benefits and expand influence.

For tourists, festivals mode is an effective access to physical and mental pleasure and emotional resonance in the modern tourism development activities. For the purpose of expanding investment and promoting cultural exchanges, the festivals mode has become a fashion in modern tourism activities. For example, Rio de Janeiro Carnival and Qingdao
Beer Festival are typical festivals widely known at home and abroad.

If Yangjiabu village can take advantage of the paintings culture resources to organize the relevant festivals, the festival activities can improve the visibility of Yangjiabu village to a large extent. Yangjiabu village and Weifang city can promote extensively exchanges with countries all over the word. The festival activities can let the world know Weifang. Weifang and Yangjiabu village also can expand the development of international cultural tourism.

\section{CONCLUSION}

The research serves a starting point for Yangjiabu's spring festival paintings culture tourism. With the development of tourism, sightseeing tourism already can't satisfy people's needs. Tourists tend to get different experience from the different culture. In the context of the revival of traditional Chinese culture, traditional culture tourism becomes more and more popular. At present, the development and utilization of Yangjiabu's woodblock Spring festival paintings culture are confronted with a series of shortages and problems. Lower level development is the most serious problem. The huge potential of Yangjiabu's woodblock Spring festival paintings culture is far from being drugged out. The government departments and related enterprises should grab the opportunity and treat the culture tourism development as an urgent priority. Specifically, the government and social organizations should develop the paintings regional humanities connotation and build their own unique folk tourism culture to overcome the difficulties. Only in this way, intangible cultural heritage and cultural tourism can be combined better. At the same time, cultural tourism will strive for further improvement

\section{REFERENCES}

[1] Wu Bingan, "The only way to protect the folk art heritage", J.Art Watch. November 2007 (In Chinese)

[2] Fu Zhuo, Fan Sha, “Out of the woods: study on Yangjiabu Spring Festival paintings'marketing strategy” J. China's foreign trade , 2011 (10)) (In Chinese)

[3] Li Duanjing, Fan Sha, Fu Qiang, “Traditional Chinese Spring Festival market development status and marketing suggestions-Taking Shandong Yangjiabu Wood Spring Festival Pictures as an example”, J.Technology and Market, 2011 (7) (In Chinese)

[4] Zhang Youchen,"Study on the development of cultural brand in Shandong Province", J. Dongyue research collection, 2009 (4) (In Chinese)

[5] Ma Mouchao,"Brand Scientific Research", Beijing: China market publishing house, 2005 edition, page 1-3 (In Chinese)

[6] Lv Qinghua, "Study on the industrial development of intangible cultural heritage - Taking Quanzhou as an example”, J. Journal of Quanzhou normal College (Social Science Edition) .2008 (3) 